PROBLEMS

OF EDUCATION IN THE $21^{\text {st }}$ CENTURY Vol. 78 , No. 4, 2020

500

\section{LECTURERS' EXPERIENCE IN ASSESSING 21ST-CENTURY MATHEMATICS COMPETENCY IN INDONESIA}

Sintha Sih Dewanti

Yogyakarta State University \& UIN Sunan Kalijaga Yogyakarta, Indonesia E-mail: sinthasih.2018@student.uny.ac.id, sintha.dewanti@uin-suka.ac.id

Badrun Kartowagiran, Jailani, Heri Retnawati Yogyakarta State University, Indonesia E-mail: kartowagiran@uny.ac.id, jailani@uny.ac.id, heri_retnawati@uny.ac.id

\begin{abstract}
Mathematics is one of the fields that has important role in the 21st-century thinking because mathematics involves the process of logical and systematic thinking to solve problems. This makes mathematical competencies need to be developed through learning and integrated into knowledge, skills, and attitudes. When learning has facilitated the development of 21 st-century mathematical competencies, the assessment must also be able to photograph it. This research aimed to find out whether the lecturers of the Mathematics Education Study Program have conducted a 21st-century mathematics competency assessment. This research used a qualitative approach with the phenomenological method. The data were collected using in-depth interviews with each participant. The research participants were 20 lecturers from Mathematics Education Study Program who came from 12 provinces in Indonesia. Data analysis was performed by using the help of ATLAS.ti 8 software to analyze participants' transcripts and documentation, formulate important phrases or sentences, formulate meaning, bring themes up, and be integrated into in-depth descriptions of the phenomenon. The result showed that lecturers of the Mathematics Education Study Program have not focused on the 21st-century mathematics competency assessment. The assessment of each mathematical competency was only done globally and not carried out in detail about each of the competency indicators.
\end{abstract}

Keywords: 21st-century mathematical competencies, competency assessment, lecturers' experience in assessment, Mathematics Education Study Program lecturers.

\title{
Introduction
}

In the 21st-century, people will experience rapid changes in globalization, demographic transformation, and advanced technology, so there will be opportunities to explore new things. Therefore, fundamental education reforms are needed in society in the 21st-century (Cheng, 2017). Educators are currently obliged to make self-adaptations and certain changes to utilize all the potential successfully that exists in the Industrial 4.0 era (Gleason, 2018). Students experienced changes in thinking patterns, ways of learning, and ways of acting in developing creative innovations in various fields. Educators were expected to be able to manage to learn, so students will have the 21 st-century competence. This is because the success of a student depends on his or her 21st-century competence (Rotherdam \& Willingham, 2009).

The 21st-century competency learning objectives have become important discussion topics throughout the world (European Union, Education and Culture DG, 2007; Pellegrino \& Hilton, 2012; Voogt \& Roblin, 2012). The 21st-century competence refers to educational goals 
or learning outcomes that are appropriate to the abilities needed in the 21st-century (Binkley et al, 2012; NEA, 2011; P21, 2002; Trilling \& Fadel, 2009; Wagner, 2008). Various terminology is used to describe 21 st-century competencies, which include generic competencies, main competencies, transversal competencies, and interdisciplinary skills. However, these competencies have almost the same meaning and content (Fullan \& Scott, 2014; Iurina \& Gorlova, 2018; UNESCO, 2016; Wang et al, 2018).

Many research findings revealed the important reasons for focusing on the 21st-century competencies (Ananiadou \& Claro, 2009; Dede, 2010; Dumont et al, 2010; Fullan \& Langworthy, 2014; Griffn et al, 2012; Pellegrino \& Hilton, 2012). This showed that the education system needs to be improved to keep pace as the time changes, including optimizing learning. One way to optimize learning is innovating through technology to deepen and improve it, as well as establish education that is more relevant to everyday life.

Mathematics is one of the fields of study that has important role in the 21 st-century thinking (Vale, 2018). In the present time, mathematics no longer emphasized arithmetic because it has been replaced with a calculator and computer. Mathematics emphasized more on the thinking process in the order of several logical and systematic steps to solve a particular problem. Mathematics is not a matter of entering numbers into formulas and doing rote calculations, but mathematics is more about ways of thinking and exploring things that are still considered odds to students (Paulos, 1995).

In general, the characteristics of mathematics are having abstract study objects, referring to agreements, deductive, axiomatic, formal, hierarchical, and consistent in the system, having meaningful symbols, and paying attention to the universe of speech. Because of this, mathematics teachers must be able to bridge between mathematical characteristics and student characteristics. Teachers need to develop learning models that able to facilitate the 21 st-century competencies development and then assess these competencies. It is intended that students will have competence in global society (Rotherham \& Willingham, 2009; P21, 2019; Truesdell \& Birch, 2013).

In this modern era, the problems of developing students' mathematical competencies become important (Alpysov et al, 2017). This is because the community needs individuals who can cause new problems and find innovative solutions in the uncertainty conditions (Makhashova et al, 2016; Sakenov et al, 2012). The mathematical competencies have also been identified throughout the world as one of the main competencies for personal fulfillment, social and economic inclusion in the 21st-century knowledge society (Vorobjovs, 2017). Although the establishment of certain aspects of students' mathematical competencies has been extensively studied (Alpyssov et al, 2016; Salekhova et al, 2014), research on developing students' mathematical competencies is still lacking. Some researchers have also formulated special competencies that are considered as important factors in the development of students' mathematical competencies (OECD, 2012; Omarov et al, 2016; Zhumasheva et al, 2016).

Mathematical competencies include two kinds of overall abilities, which are 1) the ability to ask and answer questions in mathematics, and 2) the ability to understand and use mathematical language and tools (Niss, 2003; Niss \& Højgaard, 2011; Zeidmane, 2013). The ability to ask and answer questions in mathematics includes mathematical thinking competencies, competencies in dealing with problems, mathematical modeling competencies, and reasoning competencies (giving mathematical reasons). While the ability to understand and use language and mathematical tools includes the competence of mathematical representation, the competency of using symbols and formal mathematics, the competence of mathematical communication, and the competency of using tools or information technology.

The implementation of the 21 st-century mathematical competencies assessment becomes a serious challenge because it is demand of curriculum reform that emphasizes learning experiences (Cheng, 2017). In recent years, researchers have assessed mathematical 
Sintha Sih DEWANTI, Badrun KARTOWAGIRAN, JAILANI, Heri RETNAWATI. Lecturers' experience in assessing 21st-century mathematics competency in Indonesia

PROBLEMS

OF EDUCATION

IN THE $21^{\text {st }}$ CENTURY Vol. 78 , No. 4, 2020

502

competencies on large scales such as TIMSS and PISA by using advanced statistical methods (Reiss et al, 2019). Nevertheless, the focus for classroom assessment is still measuring on the ability of students to remember facts, measure students' abilities to think complexly and problem-solving. Then, problems also often arise from the test instruments that were used. The test instrument has not been designed to measure how well students can apply what have already known to a new situation and evaluate how students solve the problems using technological assistance. Also, the test instruments have not been designed to help teachers evaluating predetermined learning targets. This assessment will eventually lead to the gap between students' knowledge and the competencies needed in the 21 st-century.

\section{Research Problem}

Ideally, an assessment must be creative, integrative, practical, and collaborative by assessing students' learning from multiple aspects. Assessment strategies required changes to meet today's world demands so that the assessment can measure complex capabilities. The assessment was carried out in detail and stages starting from assessment to measure knowledge, measure the ability to think mathematically, and the ability to examine problems. Moreover, assessments can also be done in more detail, such as assessment for measuring the ability to gather information, to make information, and to make reasons for decisions on the use of technology.

However, based on the assessment report conducted by the lecturers, it did not show the learning assessment from multiple aspects. The assessment report has not been able to provide a clear picture of the process and results of 21 st-century mathematics competency assessment. The 21 st-century mathematics competency assessment will involve various activities, one of them is the process of understanding students' mathematical thinking. The process of understanding students' mathematical thinking can be done through students' explanations, strategies, and mathematical behavior, which will be far more complex than the way teachers think about mathematical concepts and mathematics learning (Even, 2005; Watson, 2006). Therefore, teachers need diverse ways of thinking about planning, learning, and assessing. Some research results indicated that there were variations in the teacher applying innovative assessment practices based on the concepts of learning and mathematics assessment (Brookhart, 2003; Duncan \& Noonan, 2007). Thus, the accuracy of lecturers in the practice of mathematics competency assessment is important in evaluating learning that has been done and will affect the planning of subsequent mathematics learning. Therefore, the exploration of lecturers' experience in assessing 21st-century mathematics competence needs to be done.

\section{Research Focus}

Based on this description, it is necessary to review the assessment that has been done so far, by identifying competencies and assessment standards that are relevant to 21 stcentury mathematics competencies, and then determining how best to assess the acquisition of student competencies. This research aimed to find out whether the Mathematics Education Study Program lecturers have assessed the 21 st-century mathematical competencies. The assessment of learning must be relevant to the learning conducted. Therefore, researchers will also investigate whether learning by lecturers has facilitated the development of 21 st-century mathematical competencies. 
Sintha Sih DEWANTI, Badrun KARTOWAGIRAN, JAILANI, Heri RETNAWATI. Lecturers' experience in assessing 21st-century mathematics competency in Indonesia

Realizing the importance of 21 st-century the accuracy of mathematics competency assessment, this study specifically aimed to explore 21st-century planning, learning, and assessment of mathematics competence. Thus, this research is directed to answer the following research questions:

1. How the Mathematics Education Study Program lecturers do the planning, learning, and assessing of mathematics competencies?

2. What kinds of mathematical competencies are developed in the learning, and then do in the assessments?

\section{Research Methodology}

\section{General Background}

This research used a qualitative approach with the phenomenological method. Phenomenology can be defined as the study or investigation of how things appeared, were given, or presented themselves to us in pre-reflective or life experiences (van Manen \& van Manen, 2014). This research aimed to unfold the paradigm or perspective of lecturers on the assessment of 21 st-century mathematics competence. This perspective can be seen in the behavior or the experience of lecturers in conducting assessments. The experiences of lecturers will be identified as in-depth and thoroughly to get the meaning of 21st-century mathematics competency assessment. This research was conducted for 5 months, starting from August to December 2019. This research was expected to be the basis for further research, especially to develop 21st-century mathematics competency assessment.

\section{Participants}

The research participants were 20 lecturers from the Mathematics Education Study Program in 12 provinces in Indonesia. The number of participants based on recommendations from Polkinghorne (1989) that researchers should interview 5 to 25 people whom all experienced the phenomenon. The selected participants were considered by gender, higher education institutions in Indonesia, and lecturers' academic degrees. The composition of the participants were 13 male lecturers and 7 female lecturers. There were 7 lecturers from public universities, 7 lecturers from private universities, 2 lecturers from public institutes, 3 lecturers from private institutes, and 1 lecturer from private colleges. There were 5 lecturers with doctorates, 12 lecturers were doctoral candidates, and 3 lecturers had master degrees.

\section{Instrument and Procedures}

Data collection was done through in-depth individual interview (Creswell, 2007). Interviews were conducted in 60 to 90 minutes duration to reveal the following aspects: 1) lecturers' experience in planning and conducting learning that facilitates students in developing 21 st-century mathematics competencies; 2) lecturers' experience in planning and evaluating 21st-century mathematics competencies; 3 ) expectations for planning, implementation of learning, and assessments that have not been achieved; and 4) strategies taken by lecturers to achieve these expectations. During the interview, the researcher also studied the assessment documents made by the participants, to obtain data or information about the planning and practice of mathematics competency assessment. Moreover, the researcher tried to create a conducive atmosphere, so the participants felt comfortable and free in responding to every question raised (Moustakas, 1994). 
Sintha Sih DEWANTI, Badrun KARTOWAGIRAN, JAILANI, Heri RETNAWATI. Lecturers' experience in assessing 21st-century mathematics competency in Indonesia

PROBLEMS

OF EDUCATION

IN THE $21^{\text {st }}$ CENTURY Vol. 78 , No. 4, 2020

504

Data Analysis

The phenomenological method was used in analyzing participant transcripts (Colaizzi, 1978). All transcripts were read several times to get overall information about participants. From each transcript, the researcher identified important sentences related to the lecturer's experience in planning and evaluating 21 st-century mathematics competencies. Then the researcher formulated the meanings based on important statements and phrases. Then, the meanings that have been formulated are grouped into themes (general themes) that were applied to all participant transcripts. The results of grouping themes then were described in depth based on these phenomena. After the description and themes were obtained, the researcher validated the findings by meeting several participants for the second time. If there were new relevant data, then the data were included in the final description.

Analytical reduction of participants' experiences in the implementation of learning and assessment of 21st-century mathematical competencies become an important part of data analysis in this study. The researcher used the help of ATLAS.ti 8 software in analyzing data with the following steps: 1) creating a Heurmeunistic Unit; 2) inputting data by creating several Primary Documents; 3) choosing data and making several quotations; 4) providing coding; 5) making a network picture; 6) making a memo by commenting on each data; and 7) producing an output in the form of data presentation and visualization.

Trust in methodology was done through verification, validation, and validity (Meadows $\&$ Morse, 2001). Verification was done through literature search activities, following the phenomenological method, grouping experiences, making field notes, using adequate samples, identifying negative cases, and conducting interviews until data integrity is achieved (Frankel, 1999; Meadows \& Morse, 2001). Validation is an evaluation in a project carried out by various data collection methods, such as interviews and document studies. Also, validation can be done by analyzing and coding data by more experienced researchers, checking participants, and key informants, as well as audit trails. Validity is the goal of research based on trust reviews.

\section{Research Results}

Based on the results of in-depth interviews and documentation studies, several things that can be revealed were: 1) lecturers' understanding of 21 st-century mathematics competence; 2) lecturers' experiences in planning and conducting learning which facilitates students in developing 21 st-century mathematical competencies, and 3) lecturers 'experience in planning and evaluating 21 st-century mathematics competence. Also, lecturers' expectations about planning, implementation of learning, and assessment have not been achieved, as strategies that have been carried out by lecturers to achieve these expectations.

Based on data analysis, the network obtained from the research findings as in Figure 1. Figure 1 explained when talking about assessment, it certainly cannot be separated from the learning that is conducted. Precisely, measurement was the first step of learning. Without measurement, there will be no assessment, without assessment, there will be no feedback, and without feedbacks, there will be no understanding knowledge of learning outcomes. Furthermore, without knowledge of learning outcomes, there will be no systematic improvements in learning. Evaluations that have been done well and correct can improve the quality and learning outcomes. Evaluation activities can help lecturers to improve learning and help students to improve their learning, which aims to improve student achievement. In the learning system, evaluation was one of the important components and stages that must be taken by the lecturers to determine the effectiveness of learning. The results obtained from the evaluation can be used as feedback for lecturers on improving and completing programs and learning activities. 


\section{Figure 1}

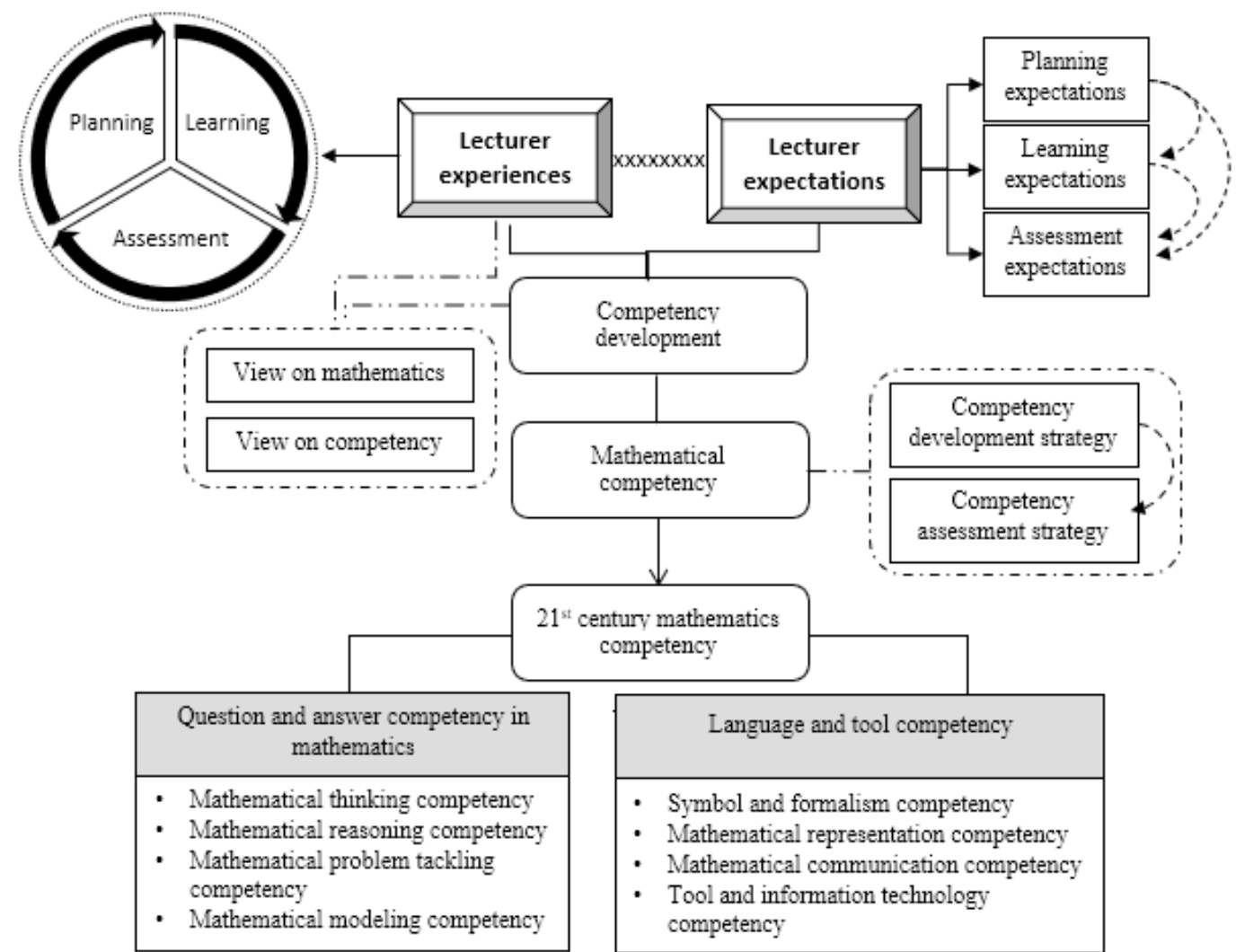

Lecturers' Understanding of 21st-Century Mathematical Competencies

Talking about mathematical competencies, it certainly cannot be separated from the lecturers' views on mathematical competencies and their characteristics. Competence was different from skills. Skills were the ability to complete tasks or problems, while competence was the ability to apply learning outcomes to a particular context, for example in the field of education and work. Competence was not limited to cognitive aspects, but also included psychomotor aspects and involved affective aspects. These three aspects differed in their emphasis. Affective aspect involved the use of theories, concepts, or knowledge. The psychomotor aspect involved technical skills, while affective aspects involved social skills and ethical values.

Mathematical competency is a mathematical way of thinking skills, which included creative thinking and innovation, critical thinking, problem-solving, decision-making, and metacognition. This is because mathematics was a pattern of thinking, organizing patterns, and logical proof. Mathematics is used as a language that can define clearly, accurately, and accurately on its representation. Mathematics can also be understood as an organized structure of knowledge. The nature of mathematics is deductively made based on elements that are not defined and axioms. Science or content of mathematics has not changed, just the application of mathematics today is more complex in various fields. Therefore, the way to learn mathematics demands changes.

Lecturers' understanding of 21 st-century mathematical competencies was very diverse. Most lecturers understand 21st-century mathematical competencies as same as 21 st-century 
Sintha Sih DEWANTI, Badrun KARTOWAGIRAN, JAILANI, Heri RETNAWATI. Lecturers' experience in assessing 21st-century mathematics competency in Indonesia

PROBLEMS

OF EDUCATION IN THE $21^{\text {st }}$ CENTURY Vol. 78, No. 4, 2020

506

competence in general, which consists of critical thinking and mathematical problem solving, mathematical communication, collaboration, creativity, and innovation. Other lecturers understand 21st-century mathematical competencies as Higher Order Thinking Skills (HOTs) in mathematics. This understanding will certainly influence lecturers in planning their learnings and assessments.

\section{Planning and Learning that Facilitates the Development of 21 st-Century Math Competence}

The planning course started with the preparation of the semester learning plan. The preparation of the semester learning plan was focused on the study program curriculum that was used as a reference, mainly in terms of decreasing course-learning achievement, which refers to the graduate learning achievement listed in the curriculum. Learning methods, assignments given, and assessments were adjusted to the characteristics of the course. In their learning, lecturers have applied various innovative learning methods, for example, Problem Based Learning, discovery learning, inquiry, and also using technology as supporting tool, for instance, blended learning using Learning Management System/ LMS (Moodle).

Problem-solving becomes the main competency that was developed for students. Problemsolving is the ability to produce solutions to mathematical problems. In solving problems, students can use trial and error methods until they find a solution. Activities undertaken by students were: 1) classifying problems to compare, differentiate, sort, and classify objects; 2) using logic and reasoning to produce solutions to problems, and 3) planning and sorting, and developing by following multi-steps to achieve goals.

In addition to problem-solving, competencies that were developed in mathematics learning are mathematical thinking competence, mathematical modeling competence, and mathematical reasoning competence. Lecturers have facilitated the development of mathematical thinking competence in learning, namely through discussions to broaden the scope of the concepts by abstracting mathematical properties and generalizing results to larger objects, so students can understand and handle the scope and limit of the concepts that were given. However, so far students have not been trained to ask questions, know the types of answers, and distinguish between various types of mathematical statements, including conditioned statements, statements containing quantitative, guesses, assumptions, definitions, theorems, and special cases.

On the other hand, students also need to be facilitated in developing the ability to understand and use language and mathematical tools. Those abilities included the competence of mathematical representation, the competency of using symbols and formal mathematics, the competence of mathematical communication, and the competence of using tools or information technology. Students learned to decode, interpret, differentiate between codes, then use various types of mathematical representations, phenomena, and problems, including the use of symbols, algebraic operations, data presentation, geometric shapes, graphical representations, diagrams, and tables, as well as concrete representations of a material object. However, students did not understand the interrelationships between various forms of representation of the same thing, students did not know the strengths and weaknesses of representation and added the missing information. The competence of tools and tools means that they can utilize and relate to mathematical tools and aids.

\section{1st-Century Planning and Evaluation of Mathematical competencies}

All of those mathematical competencies have developed in learning and assigning tasks. Nevertheless, so far there has not been a detailed assessment of mathematical competencies about each of the competency indicators. The assessment so far was more focused on the ability 
Sintha Sih DEWANTI, Badrun KARTOWAGIRAN, JAILANI, Heri RETNAWATI. Lecturers' experience in assessing 21st-century mathematics competency in Indonesia

PROBLEMS

OF EDUCATION

IN THE $21^{\text {st }}$ CENTURY

Vol. 78 , No. 4,2020

to understand the mathematical concept and problem solving in general. The 21 st-century mathematical competencies assessment conducted by the Mathematics Education Study Program lecturers is summarized in Table 1.

Table 1

Assessment of 21st-century mathematical competencies conducted by lecturers

\begin{tabular}{lll}
\hline \multirow{2}{*}{$\begin{array}{l}\text { Math } \\
\text { competence }\end{array}$} & Mathematical competencies assessment \\
\cline { 2 - 3 } & Already done by the lecturers & Have not done by lecturers \\
\hline
\end{tabular}

\begin{tabular}{|c|c|c|}
\hline $\begin{array}{l}\text { Mathematical } \\
\text { thinking } \\
\text { competency }\end{array}$ & $\begin{array}{l}\text { An assessment of the understanding and ways } \\
\text { of dealing with the scope and limits of a given } \\
\text { concept, as well as an assessment based on } \\
\text { the scope of the concept, namely abstracting } \\
\text { the nature of mathematics and generalizing } \\
\text { findings to a broader scope. }\end{array}$ & $\begin{array}{l}\text { Assessment of the ability to ask mathematical } \\
\text { questions, the ability to know different types of } \\
\text { answers, and the ability to distinguish different } \\
\text { types of mathematical statements. }\end{array}$ \\
\hline $\begin{array}{l}\text { Problem tackling } \\
\text { competency }\end{array}$ & $\begin{array}{l}\text { Assessment of students' abilities in identifying } \\
\text { and determining various types of mathematical } \\
\text { problems, including applied problems and } \\
\text { closed problems, and then solving problems. }\end{array}$ & $\begin{array}{l}\text { Assessment in identifying and raising problems } \\
\text { has not used open problems. Students are } \\
\text { not accustomed to raise problems, because } \\
\text { lecturers usually raise problems. }\end{array}$ \\
\hline
\end{tabular}

\begin{tabular}{|c|c|c|}
\hline $\begin{array}{l}\text { Modelling } \\
\text { competency }\end{array}$ & $\begin{array}{l}\text { Assessment in coding models, for example, } \\
\text { translating and interpreting model elements, } \\
\text { as well as modeling in specific contexts, for } \\
\text { example structuring the model, calculating } \\
\text { mathematically, completing the model. }\end{array}$ & $\begin{array}{l}\text { Assessment in analyzing the foundation and } \\
\text { nature of the model; validate the model; analyze } \\
\text { and criticize models by providing alternative } \\
\text { models; monitor and control the modeling } \\
\text { process; and communicating models and } \\
\text { modeling results. }\end{array}$ \\
\hline $\begin{array}{l}\text { Reasoning } \\
\text { competency }\end{array}$ & $\begin{array}{l}\text { Assessment to find out whether the } \\
\text { mathematical proof provided is correct and } \\
\text { to formulate formal mathematical arguments } \\
\text { to become valid proof, namely a statement of } \\
\text { proof. }\end{array}$ & $\begin{array}{l}\text { Assessment of the ability of students to assess } \\
\text { the chain of arguments submitted by others; } \\
\text { expressing the basic ideas of certain arguments; } \\
\text { construct mathematical arguments; turning } \\
\text { heuristic arguments into valid evidence. }\end{array}$ \\
\hline $\begin{array}{l}\text { Representing } \\
\text { competency }\end{array}$ & $\begin{array}{l}\text { Assessment of students' abilities in } \\
\text { understanding and utilizing representations, } \\
\text { by decoding, differentiating, and interpreting } \\
\text { various types of mathematical objects. }\end{array}$ & $\begin{array}{l}\text { Assessment of students' abilities in } \\
\text { understanding and utilizing relationships } \\
\text { between different representations of the same } \\
\text { thing, and also knowing the strengths and } \\
\text { limitations of representation. }\end{array}$ \\
\hline $\begin{array}{l}\text { Symbol and } \\
\text { formalism } \\
\text { competency }\end{array}$ & $\begin{array}{l}\text { Assessment of students' ability to translate from } \\
\text { natural language to symbolic language, then } \\
\text { handle symbols and manipulate statements } \\
\text { and expressions in the form of formulas and } \\
\text { symbols. }\end{array}$ & $\begin{array}{l}\text { Assessment of students' ability to describe and } \\
\text { interpret mathematical symbols and understand } \\
\text { the relationships between symbols; understand } \\
\text { the nature and rules of formal mathematics. }\end{array}$ \\
\hline $\begin{array}{l}\text { Communicating } \\
\text { competency }\end{array}$ & $\begin{array}{l}\text { Assessment of students' ability to understand } \\
\text { written text, visual, or oral form of mathematical } \\
\text { content. }\end{array}$ & $\begin{array}{l}\text { Assessment of students' ability to express } \\
\text { themselves in the accuracy of mathematical } \\
\text { content and procedures in oral, visual, or written } \\
\text { form. }\end{array}$ \\
\hline $\begin{array}{l}\text { Aids and tools } \\
\text { competency }\end{array}$ & $\begin{array}{l}\text { Skills assessment using mathematical teaching } \\
\text { aids and mathematical software. }\end{array}$ & $\begin{array}{l}\text { Assessment to find out the existence and nature } \\
\text { of various teaching aids and mathematical aids, } \\
\text { as well as their scope and limitations. }\end{array}$ \\
\hline
\end{tabular}


Sintha Sih DEWANTI, Badrun KARTOWAGIRAN, JAILANI, Heri RETNAWATI. Lecturers' experience in assessing 21st-century mathematics competency in Indonesia

PROBLEMS

OF EDUCATION IN THE $21^{\text {st }}$ CENTURY Vol. 78, No. 4, 2020

508

Table 1 shows that lecturers have not focused on 21 st-century mathematical competencies assessment. This indicated in every mathematical competency assessment was only done globally and not carried out in detail.

\section{Lecturers' Expectations on Planning, Learning, and Assessment}

Lecturers' expectations of learning were students who could use various types of reasoning that was appropriate to the problem situation, then analyzed the interactions between parts to produce a whole in a complex system. Learning objectives and assessments were expected to photograph the ability of students in 1) analyzing and evaluating evidence and arguments effectively; 2) analyzing and evaluating the main alternative viewpoints; 3 ) synthesizing and making connections between information and arguments; 4) interpreting information and drawing conclusions based on analysis; 5) thinking critically about learning experiences and processes; 6) solving various types of problems in conventional and innovative ways; and 7) identifying and asking important questions to clarify various perspectives and better solutions.

\section{Strategies Done by Lecturers to Achieve Expectations}

Strategies taken by lecturers to achieve those expectations were in the form of strategies for developing and evaluating mathematical competencies. In planning learning, lecturers determined which mathematical competencies will be developed. In this case, the semester learning plan was strived to facilitate the development of all 21 st-century mathematical competencies, both abilities related to mathematical content, as well as the ability to use language and mathematical tools. The model or method of learning that was chosen must support the development of these mathematical competencies. The strategy in evaluating mathematical competencies for students was by compiling items with a grid referring to $21 \mathrm{st}-$ century mathematical competency indicators. Then the scoring rubric was also adjusted for the competency indicator to be measured. Giving feedback needed to be done because with feedback students will find out how 21 st-century mathematical competencies were measured.

\section{Discussion}

Mathematics was considered as one of the most important subjects in school curricula all around the world. The importance of mathematics was expressed by participants when describing their views on the development of mathematics from the past to the present. Mathematics was used to look for patterns, and then the patterns were used to formulate new conjectures. Through abstraction and logic, mathematics was developed starting from counting, calculating, measuring, and last was systematic studying. Mathematics was used to formulate new conjectures and construct truth through deductive methods derived from corresponding axioms and definitions. This is consistent with the opinion of D'Ambrosio $(2007,2015)$ that mathematics is considered as the backbone of civilization, the basis of science and technology.

Mathematics has not changed from then until now when viewed from the standpoint of science or its content. It is just that today's mathematics applications are more complex in various fields, so there is a change in the way of learning mathematics. In the current time, mathematics is very much in line with technology, especially with data science concepts. This is in line with the opinion of Fajemidagba et al (2012) that stated mathematics is used as a tool for the advancement of all scientific disciplines, such as technology, industry, and astronomy.

Mathematics simplified long statements through symbols, helping to express ideas in a precise, concise, and sharp form (Kalhotra, 2013). Mathematics used representations to make conclusions, to ask questions, and tends to be more "mathematical" when dealing 
with new problems for which the solution is unknown. Mathematics emphasized more on the ratio (reasoning), not emphasizing the results of experiments or the results of mathematical observations because human thoughts are related to ideas, processes, and reasoning.

The description above indicated that mathematics has the following characteristics: 1) the study of patterns and relationships for interweaving between topics; 2) ways of thinking that can provide strategies for organizing, analyzing and synthesizing data; 3) the language defined in the symbol used to communicate; and 4) tools used to deal with daily life. This made the reason that mathematics cannot be taught as memorization, but mathematics is now more focused on the thinking process so that mathematics learning become more meaningful and the development of mathematical competencies can be facilitated appropriately.

Mathematical competencies have been identified throughout the world as one of the main competencies for personal, social, and economic needs in 21 st-century society (Vorobjovs, 2017). The opinions of the lecturers on mathematical competence can be summarized that mathematical competence was the ability to deal with mathematical and real-life problems. Mathematical competence was used to explore mathematical concepts, construct conjectures, think logically, and solve problems that are not routine, and can communicate and make connections and representations of topics in mathematics and other sciences. This is consistent with the opinion of Niss (2003) that mathematical competence can be interpreted as the ability to understand, consider, and use mathematics in various contexts and situations. Mathematical competencies in the form of knowledge and understanding to do, use, and express opinions about mathematics and mathematical activities in various contexts (Niss \& Højgaard, 2011). This implied a variety of factual, procedural, and concrete skills knowledge in the field of mathematics, but those preconditions were not enough to explain mathematical competencies. Mathematical competence is more about the readiness of information to solve a problem precisely that involves certain mathematical challenges (Niss \& Højgaard, 2011).

Mathematical competency is a major part of mathematical abilities that can be recognized and differed (Niss, 2003). The opinions of lecturers on mathematics competence can be categorized into two main competencies in mathematics, which were 1) competence to ask and answer questions in mathematics, and 2) competence to understand and use language and mathematical tools. Competencies for conducting questions and answers in mathematics were the ability to 1) ask questions and understand various types of answers (mathematical thinking competencies); 2) answer questions in and through mathematics (competence in handling problems and modeling competencies); and 3) understanding, assess and produce arguments to solve mathematical questions (reasoning competence) (Niss \& Højgaard, 2011).

Furthermore, it can be said that mathematical thinking competencies meant mastering mathematical thinking. This competence is the ability of students to understand various types of questions that characterize mathematics, also the ability to ask questions and understand different types of answers (Zeidmane, 2013). Students who have tackling competency problems will be able to formulate and solve a mathematical problem. Students can submit problems by detecting, formulating, limiting and defining problems. The type of raised problem can be in the form of pure and applied mathematical problem or open and closed problems. In every learning, it is necessary to facilitate the development of the problem-tackling competency. Those competencies have often been trained to students, but students still often experience difficulties in transforming problems, which are shown by students' mistakes in developing mathematical models, errors, in determining formulas to solve problems, and difficulties in planning to solve problems (Hadi et al, 2018).

Extensively, 21st-century mathematical competencies will affect individual's mindset which affects actions that will be taken. Competencies that support the development of critical thinking include mathematical thinking competency, problem-tackling competency, modeling competency, and reasoning competency. In this 21 st-century, critical thinking becomes a very 
Sintha Sih DEWANTI, Badrun KARTOWAGIRAN, JAILANI, Heri RETNAWATI. Lecturers' experience in assessing 21st-century mathematics competency in Indonesia

PROBLEMS

OF EDUCATION IN THE $21^{\text {st }}$ CENTURY Vol. 78, No. 4, 2020

510

important ability because many activities require critical thinking, including designing and managing projects, solving problems, and making effective decisions using various tools and resources (Fullan, 2013). Critical thinking involves evaluating, analyzing, synthesizing, and interpreting something to assess or promote thinking or assessing ideas, facts, and methods from different perspectives (Mason, 2007; Villalba, 2011), while problem-solving refers to the systematic process in which students overcome obstacles and move from the initial state to the goal state (Ward, 2011). Drake (2014) highlights challenges in designing learning activities that involve solving real-world problems that may not have clear answers. Critical thinking requires students to obtain, process, interpret, rationalize, and analyze information critically which is sometimes often in conflict, to make decisions and take appropriate actions (C21, 2012). Mathematical aids and teaching aids can support critical thinking processes, mainly used to create authentic and relevant learning experiences, so that they can help students discover, create, and use new knowledge (Fullan \& Langworthy, 2014).

On the other hand, representing competency, symbol and formalism competency, communicating competency, aids and tools competency will support the development of communication skills. In this 21 st-century, communication skills not only refer to the ability to communicate effectively, both verbally in writing and using digital tools, but also the skills to be a good listener (Fullan, 2013). To communicate well, students need to master three things, namely digital, writing, and speaking for various audiences (Fullan \& Scott, 2014). Trilling and Fadel (2009) write down several things that students must do to communicate clearly. Students can use verbal, written, and nonverbal communication skills in various forms and contexts to articulate thoughts and ideas effectively. Students need to listen effectively to be able to decipher the meanings, then use communication for various purposes. Students can utilize media and technology, so they can communicate effectively in diverse environments and can assess the effectiveness and impact of communication.

The eight 21 st-century mathematical competencies were needed in developing individual creativity that will support the innovation needed by the wider community. Creativity is an active process that must be involved when someone makes an innovation (O'Sullivan, 2018). By using creative thinking, students can apply their imagination to generate ideas, questions, and hypotheses, then experiment to get alternative solutions, to evaluate ideas, processes and final products (Kampylis \& Berki, 2014). Trilling and Fadel (2009) write down several things that students must do to think creatively. Students can use various ideas making techniques, such as brainstorming on a theme, then creating new and useful ideas. Students can elaborate, refine, analyze, and evaluate their ideas to enhance and maximize creativity.

Based on the description, it can be concluded that 21 st-century mathematical competencies are very important and need to be facilitated in learning so the competencies can develop Mathematics Education Study Program students. One graduate profile of the Undergraduate Mathematics Education Study Program is to be an outstanding individual, creative mathematics educator, superior, professional, and globally competitive. Therefore, Mathematics Education Study Program students were also required to have 21 st-century mathematical competencies, so that when they become educators, they already have the stock to develop these competencies for their students. Educators are required to be able to prepare students for the world of work that has not yet been created, with technological challenges that have not yet been discovered, which are used to solve a problem that is not yet known (OECD, 2018).

Then, it needed to be measured and assessed so that feedback occurs. The success of learning to achieve specified learning outcomes was also known. The learning outcomes of the Undergraduate Mathematics Education Study Program referred to the Indonesian National Qualification Framework, which was formulated by the Higher Education Curriculum Development Team of the Ministry of Education and Culture. These 21 st-century mathematical competencies also support learning achievements which are grouped into 3 abilities, which 
were abilities in the field of work, knowledge, and managerial. Learning achievements of the to be able to make strategic decisions in the field of mathematics education based on relevant data and information. This is certainly supported by the ability in the field of work, which can apply the concepts and principles of pedagogy, mathematical didactics as well as mathematical science to carry out planning, management, implementation, evaluation, by utilizing the science and technology-oriented to life skills. To be able to apply the concept appropriately, students must be able to master the concepts, structures, materials and mathematical scientific mindset needed to carry out learning at the level of primary and secondary education and study to the next level which is the achievement of learning in the ability in the field of knowledge.

\section{Conclusions and Implications}

This study described the experience of lecturers in planning, learning, and evaluating 21st-century mathematics competencies. This experience was influenced by the lecturers' views on the nature of mathematics and competence. This view was influenced by lecturers' understanding of the scope of mathematics, the essence of mathematics, and the mathematical competencies needed in the 21 st century. Understanding the lecturers of 21 st-century mathematics competence also affected the identification of competencies and the development of competencies in learning which will certainly affect the assessments made by the lecturers. This study also revealed strategies for developing and evaluating mathematical competencies in the learning process, but there was a mismatch between the two strategies. The lecturers have not focused on the 21st-century mathematics competency assessment. The focus of the assessment so far has been on understanding mathematical concepts and problem-solving. The assessment of each mathematical competency was only done globally and not done in detail. Nonetheless, lecturers can express their hopes for the ideal 21st-century planning, learning, and assessment of mathematical competence.

There were 8 competencies developed by lecturers in learning, namely mathematical thinking competency, problem tackling competency, modeling competency, reasoning competency, representing competency, symbol and formalism competency, communicating competency, and aids and tools competency. The assessments made by the lecturers included: 1) assessment of the understanding and scope of concepts by abstracting mathematical properties and generalizing results to a broader scope; 2) assessment in identifying, submitting closed problems, then solving them; 3 ) assessment in coding and completing the model; 4) evaluation in carrying out mathematical proof; 5) assessment in understanding and utilizing mathematics by decoding, interpreting, and distinguishing between various types of objects and mathematical phenomena; 6) evaluation in translating natural language into symbolic and formal language; 7) assessment in understanding written, visual, or oral texts regarding mathematical content; and 8) and skills assessment using mathematical teaching aids and mathematical software. However, the lecturers did not have an appropriate assessment instrument yet by following the indicators of 21 st-century mathematics competence. For this reason, further research is needed to explore mathematical competency indicators in detail, then use as a basis for developing 21 st-century mathematics competency assessment models. 
Sintha Sih DEWANTI, Badrun KARTOWAGIRAN, JAILANI, Heri RETNAWATI. Lecturers' experience in assessing 21st-century mathematics competency in Indonesia

PROBLEMS

OF EDUCATION IN THE $21^{\text {st }}$ CENTURY Vol. 78 , No. 4, 2020

512

\section{References}

Alpysov, A., Kireyeva, A., Kadkalova, T., Dautova, Z., Popova, M., \& Zhubandykova, A., (2017). On the development of mathematical competencies of students in the construction and solution of complex inequalities. Espacios, 38(51), 31. http://www.revistaespacios.com/a17v38n50/ a17v38n50p31.pdf

Alpyssov, A., Mukanova, Zh., Kireyeva, A., Sakenov, J., \& Kervenev, K. (2016). Development of intellectual activity in solving exponential inequalities. International Journal of Environmental \& Science Education, 11(14), 6671-6686. https://files.eric.ed.gov/fulltext/EJ1118303.pdf

Ananiadou, K., \& Claro, M. (2009). 21st Century Skills and Competencies for New Millennium Learners in OECD Countries. EDU Working Paper No. 41. OECD Publishing. https://www.oecd-ilibrary.org/docserver/218525261154.pdf?expires $=1587187331 \&$ id=id\&accname=guest\&checksum=1285E70BC206D8890B30A4307B60F7C2

Binkley, M., Estad, O., Herman, J., Raizen, S., Ripley, M., Miller-Ricci, M., \& Rumble, M. (2012). Defining twenty-first century skills. In P. Griffn, B., McGaw, \& E. Care (Eds.), Assessment and teaching of 21st century skills (pp. 17-66). Springer.

Brookhart, S. M. (2003). Developing measurement theory for classroom assessment purposes and uses. Educational Measurement: Issues and Practice, 22(4), 5-12. https://doi. org/10.1111/j.1745-3992.2003.tb00139.x

C21 (Canadians for 21st Century Learning and Innovation). (2012). Shifting minds: A 21st century vision of public education for Canada. http://www.c21 canada.org/wp-content/uploads/2015/05/C21ShiftingMinds-3.pdf

Cheng, K., (2017). Advancing 21st century competencies in East Asian education systems. Center for Global Education: Asia Society.

Colaizzi, P. F. (1978). Psychological research as the phenomenologist views it. In R. Valle \& M. King (Eds.), Existential phenomenological alternatives in psychology (pp. 48-71). Oxford University Press.

Creswell, J. W. (2007). Qualitative inquiry \& research resign: Choosing among five approaches (2nd ed.). Sage.

D'Ambrosio, U. (2007). The role of mathematics in educational systems. ZDM Mathematics Education, 39, 173-181. https://doi.org/10.1007/s11858-006-0012-1

D'Ambrosio, U. (2015). From mathematics education and society to mathematics education and a sustainable civilization: A threat, an appeal, and a proposal. Opening address, Mathematics Education \& Society conference, Portland, Oregon. https://www.youtube.com/ watch? $=$ SsgYqt N Hg\&feature=youtu.be

Dede, C. (2010). Comparing frameworks for 21st century skills. In J. Bellanca, \& R. Brandt (Eds.), 21st century skills: Rethinking how students learn (pp. 51-75). Solution Tree Press.

Drake, S. M. (2014). Designing across the curriculum for "sustainable wellbeing": A 21st century approach. In F. Deer, T. Falkenberg, B. McMillan, \& L. Sims (Eds.), Sustainable well-being: Concepts, issues, and educational practice (pp. 57-76). Education for Sustainable Well-Being (ESWB) Press.

Dumont, H., Istance, D., \& Benavides, F. (Eds.). (2010). The nature of learning: Using research to inspire practice. Educational Research and Innovation, OECD Publishing. https://dx.doi. org/10.1787/9789264086487-en

Duncan, C. R., \& Noonan, B. (2007). Factors affecting teachers' grading and assessment practices. The Alberta Journal of Educational Research, 53(1), 1-21. https://journalhosting.ucalgary.ca/index. php/ajer/article/view/55195

European Union, Education and Culture DG. (2007). Key competences for lifelong learning: European reference framework. Office for Official Publications of the European Communities

Even, R. (2005). Using assessment to inform instructional decisions: How hard can it be? Mathematics Education Research Journal, 17(3), 45-61. https://doi.org/10.1007/BF03217421

Fajemidagba, M. Salman, M and Ayinla, O. (2012). Effect of teachers' instructional strategy pattern on senior secondary school students' performance in mathematics word problems in Ondo State, Nigeria. Journal of Education and Practice, 3 (7). https://www.iiste.org/Journals/index.php/JEP/ article/view/1861/1816 
Sintha Sih DEWANTI, Badrun KARTOWAGIRAN, JAILANI, Heri RETNAWATI. Lecturers' experience in assessing 21st-century mathematics competency in Indonesia

Frankel, R. M. (1999). Standards of qualitative research. In B. F. Crabtree \& W. L. Miller (Eds.), Doing Vol. 78 , No. 4, 2020 qualitative research (2nd ed., pp. 333-346). Sage.

Fullan, M. (2013). Great to excellent: Launching the next stage of Ontario's education agenda. Ontario Ministry of Education.

Fullan, M., \& Langworthy, M. (2014). A rich seam: How new pedagogies find deep learning. Pearson.

Fullan, M., \& Scott, G. (2014). New pedagogies for deep learning whitepaper: Education PLUS. Collaborative Impact SPC.

Gleason, N. W., (2018). Introduction. In N. W. Gleason, Higher education in the era of the fourth industrial revolution (pp. 1-12). Palgrave Macmillan. https://link.springer.com/content/ pdf/10.1007\%2F978-981-13-0194-0.pdf

Griffin, P., Care, E., \& McGaw, B. (2012). The changing role of education and schools. In P. Griffin, B. McGaw, and E. Care (Eds.), Assessment and teaching of 21 st century skills. Springer.

Hadi, S., Retnawati, H., Munadi, S., Apino, E., \& Wulandari, N. F. (2018). The difficulties of high school students in solving higher-order thinking skills problems. Problems of Education in the 21st Century, 76(4), 520-532. http://oaji.net/articles/2017/457-1533495738.pdf

Iurina, M. \& Gorlova, E. (2018). Adopting 21 st century competencies for a technical university curriculum. Proceedings of the International Scientific Conference, Vol. I, May 25th - 26th, 2018, (pp. 159167). http://journals.rta.lv/index.php/SIE/article/download/3126/2951

Kalhotra, S.K. (2013). A study of causes of failure in mathematics at high school stage. Academic Research International, 4(5). http://www.savap.org.pk/journals/ARInt./Vol.4(5)/2013(4.5-58).pdf

Kampylis, P. \& Berki, E. (2014). Nurturing creative thinking. International Academy of Education, UNESCO. http://www.ibe.unesco.org/sites/default/files/resources/edu-practices_25_eng.pdf

Makhashova, P., Meirmanov, A., Zhunusbekov, Zh., Makasheva, O., Mirzaliyeva, E., Ermuratova, A., \& Sakenov, J. (2016). On the development of professional competence in students of creative pedagogical specialties. International Journal of Environmental \& Science Education, 11(11), 4660-4668. https://files.eric.ed.gov/fulltext/EJ1114947.pdf

Mason, M. (2007). Critical thinking and learning. Educational Philosophy and Theory, 39(4), 339-349. https://doi.org/10.1111/j.1469-5812.2007.00343.x

Meadows, L. M., \& Morse, J. M. (2001). Constructing evidence within the qualitative project. In J. M. Morse, J. M. Swansen, \& A. Kuzel (Eds.), Nature of qualitative evidence (pp. 187-200). Sage.

Moustakas, C. (1994). Phenomenological research methods. Sage.

NEA (National Education Association). (2011). Preparing 21st century students for a global society: An educator's guide to the "Four Cs". http://www.nea.org/assets/docs/A-Guide-to-Four-Cs.pdf

Niss, M. (2003). Mathematical competencies and the learning of mathematics: The Danish KOM project. Paper presented at the Third Mediterranean Conference on Mathematics Education. http://www. math.chalmers.se/Math/Grundutb/CTH/mve375/1112/docs/KOMkompetenser.pdf

Niss, M. \& Højgaard, T. (Eds). (2011). Competencies and mathematical learning: Ideas and inspiration for the development of mathematics teaching and learning in Denmark. Roskilde University: IMFUFA/NSM. https://pure.au.dk/portal/files/41669781/THJ11_MN_KOM_in_english.pdf

O'Sullivan, M. (2018). Developing the Cambridge learner attributes. Cambridge Assessment International Education. https://www.cambridgeinternational.org/Images/417069-developing-the-cambridgelearner-attributes-.pdf

OECD (Organisation for Economic Co-operation and Development). (2013). PISA 2012 released mathematics items. http://www.oecd.org/pisa/pisaproducts/pisa2012-2006-rel-items-maths-ENG. pdf

OECD (Organisation for Economic Co-operation and Development). (2018). The future of education and skills: Education 2030. OECD. https://www.oecd.org/education/2030/E2030\%20Position\%20 Paper\%20(05.04.2018).pdf

Omarov, Y.B., Toktarbayev, D.G., Rybin, I.V., Saliyeva, A.G., Zhumabekova, F.N., Hamzina, Sh., Baitlessova, N., \& Sakenov, J. (2016). Methods of forming professional competence of students as future teachers. International Journal of Environmental \& Science Education, 11(14), 66516662. https://files.eric.ed.gov/fulltext/EJ1116067.pdf

P21 (Partnership for 21st Century Skills). (2002). Learning for the 21st century: A report and MILE guide for 21 st century skills. https://eric.ed.gov/?id=ED480035 
Sintha Sih DEWANTI, Badrun KARTOWAGIRAN, JAILANI, Heri RETNAWATI. Lecturers' experience in assessing 21st-century mathematics competency in Indonesia

PROBLEMS

OF EDUCATION IN THE $21^{\text {st }}$ CENTURY Vol. 78 , No. 4, 2020

514

P21 (Partnership for 21st Century Skills). (2019). Framework for 21st century learning. http://www.p21. org/about-us/p21-framework

Paulos, J. A. (1995). A mathematician reads the newspaper. Anchor Books.

Pellegrino, J. W., \& Hilton, M. L. (Eds.). (2012). Education for life and work: Developing transferable knowledge and skills in the 21st century. National Research Council of the National Academies.

Polkinghorne, D. E. (1989). Phenomenological Research Methods. In R. S. Valle \& S. Halling (Eds), Existential-phenomenological perspectives in psychology: Exploring the breadth of human experience (pp. 41-60). Plenum Press.

Reiss, K., Obersteiner, A., Heinze, A., Itzlinger-Bruneforth, U., \& Lin, F., (2019). Large-Scale Studies in Mathematics Education Research. In H. N. Jahnke \& L. Hefendehl-Hebeker (Eds), Traditions in German-Speaking Mathematics Education. Research ICME-13 Monographs.

Rotherham, A. J., \& Willingham, D., (2009). 21st century skills: The challenges ahead. Teaching for the 21st century, September 2009, 67(1), 16-21. https://eric.ed.gov/?id=EJ855079

Sakenov, D. Zh., Kushnir, Y. V., Shnaider, Y., \& Abdulkhamidova, D. Zh. (2012). Preparation of students of higher education institution for professional activity in the course of studying of pedagogical disciplines. World Applied Sciences Journal, 19(10), 1431-1436. https://doi.org/10.5829/idosi. wasj.2012.19.10.2800

Salekhova, L. L., Tuktamyshov, N. K., Zaripova, R. R., \& Salakhov, R. F. (2014). Definition of development level of communicative features of mathematical speech of bilingual students. Life Science Journal, 11(8), 524-526. https://pdfs.semanticscholar.org/1db6/5f8a9639580c7af6aa0c9f1e92c09f2b6da0. pdf?_ga=2.196589548.1150687346.1587350502-808468089.1563954285

Trilling, B., \& Fadel, C. (2009). 21st century skills: Learning for life in our times. Jossey-Bass.

Truesdell, E., \& Birch, R. (2013). Integrating instructional technology into a teacher education program: A three-tiered approach. Collected Faculty and Staff Scholarship, 53. https://scholar.dominican. edu/all-faculty/53

UNESCO. (2016). School and teaching practices for twenty-first century challenges: Lessons from the Asia Pacific Region. UNESCO. https://unesdoc.unesco.org/ark:/48223/pf0000244022

Vale, C., (2018). 7 reasons why maths is important for 21st century thinking. Monash University. https:// www.monash.edu/education/teachspace/articles/seven-reasons-why-maths-is-important-for21st-century-thinking

van Manen, M.A. \& van Manen, M.J. (2014) Phenomenology. In D. C. Phillips, D.C. (Ed.) The Encyclopedia of Educational Theory and Philosophy (pp. 610-616). Sage.

Villalba, E. (2011). Critical thinking. In M. A. Runco, \& S. R. Pritzker (Eds.), Encyclopedia of creativity (2nd ed., pp. 323-325). Academic Press. https://www.elsevier.com/books/encyclopedia-ofcreativity/runco/978-0-12-375039-6

Voogt, J., \& Roblin, N. P. (2012). A comparative analysis of international frameworks for 21 st century competences: Implications for national curriculum policies. Journal of Curriculum Studies, 44(3), 299-321. https://doi.org/10.1080/00220272.2012.668938

Vorobjovs, A. (2017). Adolescents' mathematical competencies formation influencing factors. Rural environment, education, personality, Jelgava, 12-13 May, 2017. https://lufb.llu.lv/conference/ REEP/2017/Latvia-Univ-Agricult-REEP-2017_proceedings-315-320.pdf

Wagner, T., (2008). The global achievement gap: Why even our best schools don't teach the new survival skills our children need - and what we can do about it. Basic Books.

Wang. Y., Lavonen, J., \& Tirri. K. (2018). Aims for learning 21st century competencies in national primary science curricula in China and Finland. EURASIA, Journal of Mathematics, Science and Technology Education, 14(6), 2081-2095. https://www.ejmste.com/download/aims-for-learning21st-century-competencies-in-national-primary-science-curricula-in-china-and-5412.pdf

Ward, T. B. (2011). Problem solving. In M. A. Runco, \& S. R. Pritzker (Eds.), Encyclopedia of creativity (2nd ed., pp. 254-260). Academic Press.

Watson, A. (2006). Some difficulties in informal assessment in mathematics. Assessment in Education, 13(3), 289-303. https://doi.org/10.1080/09695940601035445

Zeidmane. A., (2013). Development of mathematics competences in higher education institutions. iJEP, Volume 3, Special Issue 2: “IGIP2012 Conference”, March 2013. https://online-journals.org/ index.php/i-jep/article/view/2394 
Sintha Sih DEWANTI, Badrun KARTOWAGIRAN, JAILANI, Heri RETNAWATI. Lecturers' experience in assessing 21st-century mathematics competency in Indonesia

PROBLEMS

OF EDUCATION

IN THE $21^{\text {st }}$ CENTURY

Vol. 78 , No. 4, 2020

Zhumasheva A., Zhumabaeva, Z., Sakenov, J., Vedilina, Y., Zhaxylykova, N., \& Sekenova, B. (2016). Theoretical model of development of information competence among students enrolled in elective courses. International Journal of Environmental \& Science Education, 11(18), 11249-11259. http://www.ijese.net/makale/1500.html

Received: April 20, 2020

Accepted: July 12, 2020

Cite as: Dewanti, S. S., Kartowagiran, B., Jailani, \& Retnawati, H. (2020). Lecturers' experience in assessing 21 st-century mathematics competency in Indonesia. Problems of Education in the $21^{\text {st }}$ Century, 78(4), 500-515. https://doi.org/10.33225/pec/20.78.500

$\begin{array}{|ll|}\begin{array}{l}\text { Sintha Sih Dewanti } \\ \text { (Corresponding author) }\end{array} & \text { PhD (cand), Student, Doctor Program in Research and Evaluation Education } \\ & \text { Graduate School of Yogyakarta State University, Jl. Colombo Karangmalang } \\ & \text { Yogyakarta 55281, Indonesia. } \\ \text { Lecturer, Mathematics Education Study Programs of UIN Sunan Kalijaga } \\ \text { Yogyakarta, Jl. Laksda Adisucipto Yogyakarta 55281, Indonesia. } \\ \text { E-mail: sinthasih.2018@student.uny.ac.id, sintha.dewanti@uin-suka.ac.id } \\ \text { ORCID: https://orcid.org/0000-0001-5966-1354 }\end{array}$

